\title{
Gap Junctional Coupling is Essential for Epithelial Repair in the Avian Cochlea
}

\author{
DDaniel J. Jagger, Regina Nickel, and Andrew Forge \\ Ear Institute, University College London, London WC1X 8EE, United Kingdom
}

The loss of auditory hair cells triggers repair responses within the population of nonsensory supporting cells. When hair cells are irreversibly lost from the mammalian cochlea, supporting cells expand to fill the resulting lesions in the sensory epithelium, an initial repair process that is dependent on gap junctional intercellular communication (GJIC). In the chicken cochlea (the basilar papilla or BP), dying hair cells are extruded from the epithelium and supporting cells expand to fill the lesions and then replace hair cells via mitotic and/or conversion mechanisms. Here, we investigated the involvement of GJIC in the initial epithelial repair process in the aminoglycoside-damaged BP. Gentamicin-induced hair cell loss was associated with a decrease of chicken connexin43 (cCx43) immunofluorescence, yet cCx30-labeled gap junction plaques remained. Fluorescence recovery after photobleaching experiments confirmed that the GJIC remained robust in gentamicin-damaged explants, but regionally asymmetric coupling was no longer evident. Dye injections in slice preparations from undamaged BP explants identified cell types with characteristic morphologies along the neural-abneural axis, but these were electrophysiologically indistinct. In gentamicin-damaged BP, supporting cells expanded to fill space formerly occupied by hair cells and displayed more variable electrophysiological phenotypes. When GJIC was inhibited during the aminoglycoside damage paradigm, the epithelial repair response halted. Dying hair cells were retained within the sensory epithelium and supporting cells remained unexpanded. These observations suggest that repair of the auditory epithelium shares common mechanisms across vertebrate species and emphasize the importance of functional gap junctions in maintaining a homeostatic environment permissive for subsequent hair cell regeneration.

Key words: cochlea; connexin; deafness; hair cells; hearing; repair

\section{Introduction}

Vertebrate inner ear sensory epithelia contain two principal cell types: sensory mechanoreceptors known as hair cells and nonsensory supporting cells. Hair cells are damaged most commonly by noise, ototoxic drugs, and the effects of aging (Monzack and Cunningham, 2013; Rubel et al., 2013). In the inner ear of mammals, hair cell loss may lead to hearing impairment and balance disorders, but a small degree of hair cell regeneration occurs naturally in vestibular epithelia (Forge et al., 1993; Forge et al., 1998). In nonmammalian species, inner ear epithelia produce new hair cells throughout adult life, thereby continually replacing lost cells (Stone and Cotanche, 2007; Rubel et al., 2013; Wan et al., 2013).

When hair cells die, supporting cells play a key role in the

Received May 12, 2014; revised Sept. 29, 2014; accepted 0ct. 3, 2014.

Author contributions: D.J.J., R.N., and A.F. designed research; D.J.J. and R.N. performed research; D.J.J. and R.N. analyzed data; D.J.J. and A.F. wrote the paper.

This work was supported by the Biotechnology and Biological Sciences Research Council (Grant BB/D009669/1 to A.F. and D.J.J.).

The authors declare no competing financial interests.

This article is freely available online through the J Neurosci Author Open Choice option

Correspondence should be addressed to Daniel J. Jagger, UCL Ear Institute, University College London, 332 Gray's Inn Road, London WC1X 8EE, United Kingdom. E-mail: d.jagger@ucl.ac.uk.

DOI:10.1523/JNEUROSCI.1932-14.2014

Copyright $\odot 2014$ Jagger et al.

This is an Open Access article distributed under the terms of the Creative Commons Attribution License (http://creativecommons.org/licenses/by/3.0), which permits unrestricted use, distribution and reproduction in any medium provided that the original work is properly attributed. maintenance of epithelial barrier integrity, ensuring that fluid compartments are separated and that ion homeostasis is preserved (Gale and Jagger, 2010). Dying hair cells are eliminated rapidly and the spaces they formerly occupied are filled. These "repair" processes must be undertaken before any regenerative replacement of hair cells and recovery of function can occur. After ototoxicity in the avian cochlear epithelium (the basilar papilla or BP), some apoptotic hair cells are ejected from the epithelium (Hirose et al., 2004; Mangiardi et al., 2004) and externalized hair cell corpses are broken down via controlled signaling pathways (Mangiardi et al., 2004). In mammalian and nonmammalian inner ear epithelia, another mechanism occurs whereby adjacent supporting cells excise the dying hair cell's apical cuticular plate and stereociliary bundle from the soma (Li et al., 1995; Gale et al., 2002; Rubel et al., 2013) and the cell body is phagocytosed by supporting cells (Forge, 1985; Abrashkin et al., 2006; Bird et al., 2010).

A damage response common between species is an apical expansion of supporting cells (Forge, 1985; Hirose et al., 2004; Abrashkin et al., 2006; Raphael et al., 2007; Taylor et al., 2008; Taylor et al., 2012). In the organ of Corti, inner hair cell lesions may be filled by inner border cells and inner phalangeal cells and outer hair cell lesions may be filled by Deiters' cells (Taylor et al., 2012). In addition, the Deiters' cells migrate to fill the tunnel of Corti (Taylor et al., 2012) and the columnar epithelium is subsequently remodeled as a "flat" epithelium. In the organ of Corti of 


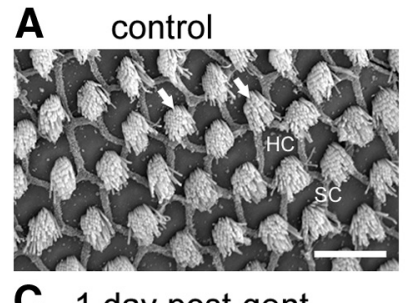

\section{1 day post-gent}
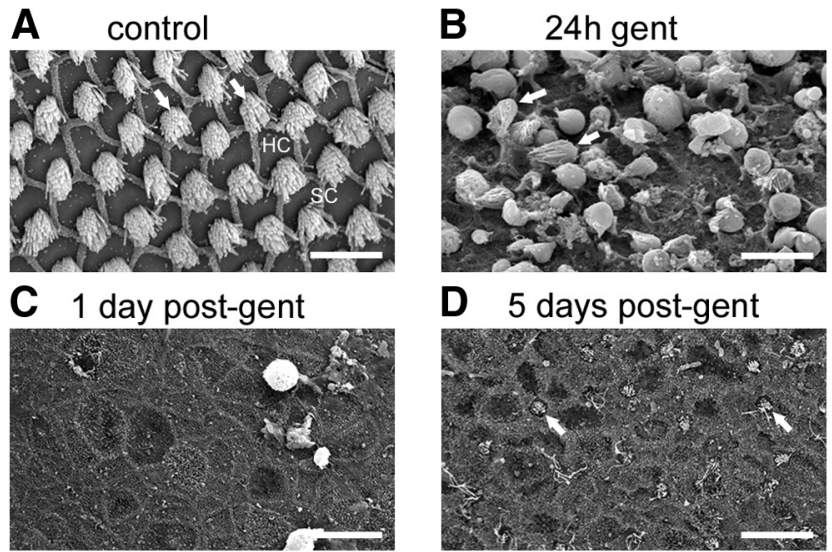

Figure 1. Ototoxic hair cell damage and regeneration in cultured BP explants. $A-D$, Scanning electron micrographs of whole-mount preparations of the chick BP cultured for $24 \mathrm{~h}$ in the absence $(\boldsymbol{A})$ and presence $(\boldsymbol{B})$ of $1 \mathrm{~mm}$ gentamicin and after recovery after gentamicin removal $(C, D) . A$, In the control BP, there is a regular mosaic of hair cells (HC) and supporting cells (SC). Each hair cell has a characteristic stereociliary bundle on the luminal surface (arrows). B, After $24 \mathrm{~h}$ of gentamicin exposure, hair cells ejected from the sensory epithelium litter the luminal surface (arrows). C, After $1 \mathrm{~d}$ of recovery, the majority of hair cell corpses are no longer apparent and lesions have been closed by the expansion of the supporting cells. $\boldsymbol{D}$, After $5 \mathrm{~d}$, immature hair bundles at different stages of maturation are visible (arrows). Scale bars, $10 \mu \mathrm{m}$.

Connexin30-null mice, the gap junctional intercellular communication (GJIC) is impaired and repair responses display peculiarities (Forge et al., 2013). Supporting cells show uncoordinated expansion and migration does not occur, implicating GJIC in normal repair. We previously characterized GJIC in supporting cells of the undamaged chicken inner ear (Nickel et al., 2006) and identified differential connexin expression coinciding with asymmetric dye coupling in which dye flowed quicker at the epithelial abneural edge than at the neural edge. Here, we investigated GJIC between BP-supporting cells during gentamicin ototoxicity. During this critical repair period, we observed dynamic changes of connexin expression, but GJIC remained robust. The repair process was impaired when GJIC was blocked pharmacologically, with reduced ejection of dying hair cells from the damaged epithelium.

\section{Materials and Methods}

Animals. Fertilized eggs of white leghorn chickens (Gallus domesticus) were obtained from a national supplier (Henry Stewart and Company) and incubated at $37.4^{\circ} \mathrm{C}$ in a humidified, rotating incubator (Octagon 20; Brinsea) for $21 \mathrm{~d}$. All data were collected from prehatch chicks of either sex at embryonic day 21 (E21).

Organotypic cultures. Cochlear ducts and utricles of chicken hatchlings (E21) were dissected in cooled Medium 199 with HBSS and $25 \mathrm{~mm}$ HEPES. The explants were placed on membrane inserts (Millicell-PCF; Merck Millipore) and incubated in Medium 199 with Earle's salts, $25 \mathrm{~mm}$ HEPES, 26 mM sodium bicarbonate, $0.69 \mathrm{~mm}$ L-glutamine, and $5 \%$ fetal calf serum in a $5 \% \mathrm{CO}_{2}$ atmosphere at $37^{\circ} \mathrm{C}$. Hair cell loss was induced by incubation in $1 \mathrm{~mm}$ gentamicin for $24 \mathrm{~h}$. Chemicals were from SigmaAldrich unless stated otherwise.

Scanning electron microscopy. Cultures were fixed in $2.5 \%$ glutaraldehyde in $0.1 \mathrm{M}$ cacodylate buffer, $\mathrm{pH} 7.3$, with $2 \mathrm{~mm} \mathrm{CaCl}_{2}$ for $2 \mathrm{~h}$. Tissues were postfixed in $1 \%$ cacodylate-buffered $\mathrm{OsO}_{4}$ and then processed through the thiocarbohydrazide- $\mathrm{OsO}_{4}$ repeated procedure (Davies and Forge, 1987) before dehydration in an ethanol series and critical point drying. They were examined in a JEOL $6700 \mathrm{~F}$ cold-field emission instrument and digital images were collected. All digital images were adjusted for optimal contrast and brightness using Adobe Photoshop CS4.

Antibodies. Protein expression of chicken Cx30 was examined using a rabbit polyclonal antibody that was generated against a synthetic amino acid peptide sequence from the cytoplasmic loop of chicken Cx30 (cCx30; aa 102-112; used at 1:100), as described in our previous study (Nickel et al., 2006), and also with a commercial rabbit polyclonal antibody raised against the $\mathrm{C}$ terminus of mouse Cx30 (71-2200, 1:200; Invitrogen) and a commercial mouse monoclonal antibody raised against the C terminus of mouse Cx30 (33-2500, 1:200; Invitrogen). cCx43 was detected using a mouse monoclonal Cx43 antibody (C8093, 1:200; Sigma-Aldrich). A commercial polyclonal antibody raised against the amino acid peptide sequence for the cytoplasmic loop of rat Cx26 (710500, 1:200; Invitrogen) and a commercial monoclonal antibody raised against the $\mathrm{C}$ terminus of mouse Cx26 (33-5800, 1:200; Invitrogen) were used in preliminary experiments to detect $\mathrm{cCx} 26$. A polyclonal antibody raised against the cytoplasmic loop of rat Cx26 (Gap 28H, 1:400; a gift from Prof. Howard Evans, University of Cardiff) was also used in these experiments. A mouse monoclonal HCS-1 (Hair Cell Soma-1) antibody was used to label hair cells (mAb76, 1:100; a gift from Prof. J Corwin, University of Virginia).

Immunofluorescence microscopy. The fixed tissues (4\% PFA for $30 \mathrm{~min}$ ) were incubated in primary antibodies diluted in PBS containing $100 \mathrm{~mm}$ L-lysine and $0.2 \%$ Triton X-100 overnight at $4^{\circ} \mathrm{C}$ and then in FITCconjugated goat anti-mouse IgG, Alexa Fluor 633-conjugated goat antirabbit IgG, and $1 \mu \mathrm{g} / \mathrm{ml}$ TRITC-conjugated phalloidin (all Invitrogen) in $\mathrm{PBS} / \mathrm{lysine/Triton} \mathrm{X}-100$ for $1 \mathrm{~h}$ at room temperature. The samples were examined by confocal laser microscopy (LSM-510; Zeiss).

Fluorescence recovery after photobleaching. Fluorescence recovery after photobleaching (FRAP) experiments were performed and analyzed as described previously (Nickel et al., 2006). Briefly, after $24 \mathrm{~h}$ in culture, cochlear ducts were opened to expose the BP and loaded for 20 min with 1-2 $\mu \mathrm{M}$ calcein-AM (Invitrogen) diluted in Medium 199 with Hanks' salt solution. After loading, culture dishes were washed several times with HBSS. Measurements were taken within the next 2-3 h on a confocal laser-scanning microscope (TCS SP2; Leica). The tissues, attached to the membrane inserts, were maintained in Medium 199 with HBSS with 25 mM HEPES at $35 \pm 2{ }^{\circ} \mathrm{C}$. A $63 \times$ water-immersion apochromatic objective lens (numerical aperture 0.9) of an upright epifluorescence microscope was used to focus just below the luminal surface of the epithelium. Optical sections were scanned in xyt mode at $1.6 \mathrm{~s} /$ frame. A $48 \mu \mathrm{m} \times 48$ $\mu \mathrm{m}$ square was bleached at maximum laser power for $32 \mathrm{~s}$. An area of 119 $\mu \mathrm{m} \times 119 \mu \mathrm{m}$ was recorded for the prebleach and postbleach scans at low laser power to minimize bleaching and fluorescence recovery was monitored over $5 \mathrm{~min}$. Postbleaching fluorescence intensity $(I)$ within regions of interest (ROIs; $\sim 7600$ pixels) was expressed in 8-bit gray-level units as a function of time using LCS 2.0 software (Leica). For each sample, the instantaneous recovery rates $(\delta I / \delta t$, at $t=0)$ from six ROIs within an optical section were expressed as mean \pm SD and tested for significance using the paired Student's $t$ test (GraphPad Prism 4).

Engineering of $c \mathrm{C} \times 26$ and $c \mathrm{C} \times 30 \mathrm{DNA}$ and transient transfection of $\mathrm{HeLa}$ cells. cCx26 and cCx30 cDNA (Nickel et al., 2006) was PCR amplified from chicken inner ear tissues and cloned into AcGFP (cCx26) and DsRed (cCx30) monomer vectors (Clontech) using the In-Fusion PCR cloning kit (Clontech) according to the recommendations of the manufacturer. The cDNA encoding the protein was verified by sequencing. Connexin-deficient HeLa cells were transiently transfected with plasmid DNA using Dreamfect (Oz Bioscience).

Whole-cell dye injections. For heterologous connexin expression experiments, HeLa cells were grown on glass coverslips. For slice preparations of the BP, cultured cochlear ducts were suspended in low-gellingtemperature agarose (type VII), mounted on a vibratome block, and sectioned at $\sim 150 \mu \mathrm{m}$ thickness. Cells or slices were transferred to a recording chamber mounted on an upright microscope and superfused with artificial perilymph containing the following (in $\mathrm{mM}$ ): $150 \mathrm{NaCl}, 4$ $\mathrm{KCl}, 2 \mathrm{MgCl}_{2}, 1.3 \mathrm{CaCl}_{2}, 10$ HEPES, and 5 glucose, $\mathrm{pH}$ adjusted to 7.3 with $\mathrm{NaOH}$. In some experiments, the artificial perilymph was supplemented with carbenoxolone or meclofenamic acid (both Sigma Aldrich) to block GJIC (Pan et al., 2007; Kelly et al., 2012; Toychiev et al., 2013). Slices were held beneath short lengths of platinum wire to prevent movement. Experiments were conducted at room temperature $\left(20-24^{\circ} \mathrm{C}\right)$. Patch-clamp recordings were performed under infrared differential interference contrast (IR-DIC) videomicroscopy using a CCD video cam- 
control
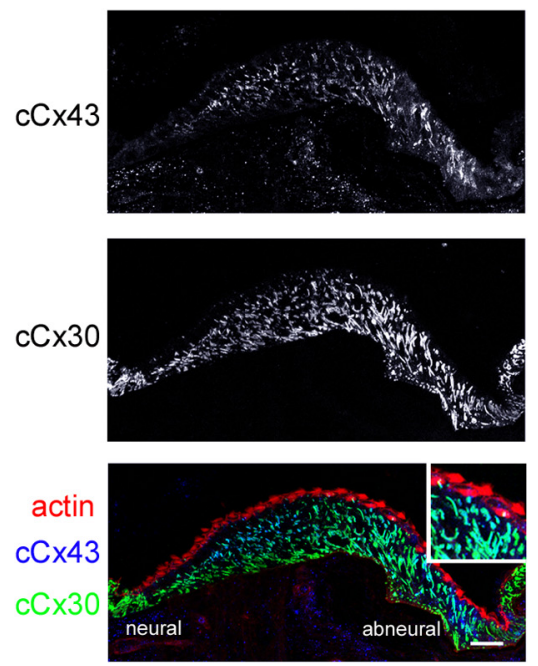

24 h gent
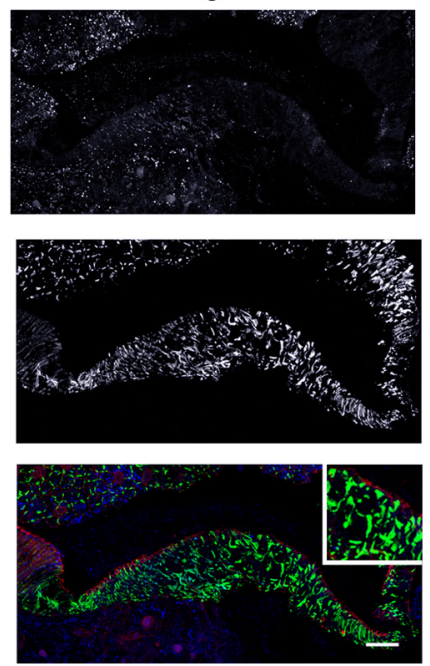

24h post-gent
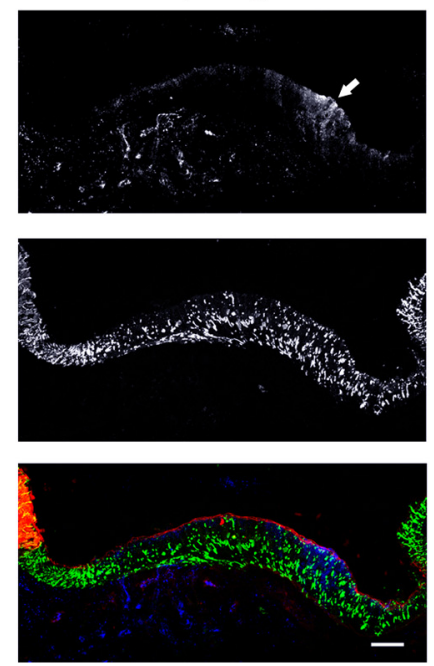

48h post-gent
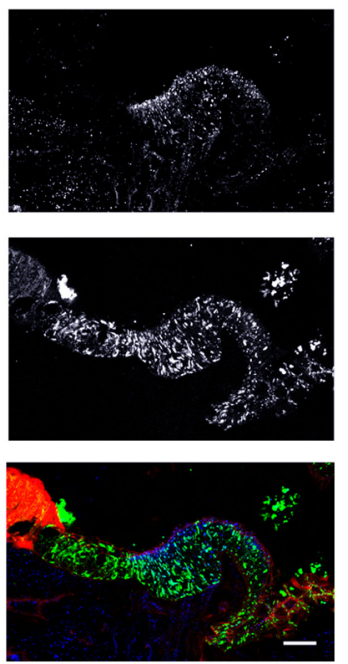

Figure 2. Changes of connexin expression in BP explants after gentamicin-induced hair cell loss. Double immunolabeling of transverse sections with antibodies to $c(x 43$ (blue) and c $C \times 30$ (green) after a $24 \mathrm{~h}$ incubation in the absence of gentamicin (control), $24 \mathrm{~h}$ in $1 \mathrm{~mm}$ gentamicin, $1 \mathrm{~d}$ after gentamicin, and $2 \mathrm{~d}$ after gentamicin. Phalloidin staining to label $\mathrm{F}$-actin is shown in red. In control cultures, there are numerous plaques double labeled with $\mathrm{c}(\mathrm{x} 43$ and $\mathrm{c}(\mathrm{x} 30$ antibodies, particularly toward the abneural edge (inset). After the death and extrusion of hair cells, $\mathrm{c}(\mathrm{C} 43$ immunostaining decreases rapidly, particularly toward the abneural edge (inset). By $1 \mathrm{~d}$ after gentamicin, small, $\mathrm{C}(\mathrm{x} 43$-positive plaques at the apical surface of the epithelium are again visible (arrow). By $2 \mathrm{~d}$ after gentamicin, $\mathrm{C} C \mathrm{x} 43-$ positive plaques reappear toward the neural edge of the BP. In contrast, $\mathrm{C} C \mathrm{x} 30$ expression levels in treated BP explants are comparable to controls. Scale bars, $20 \mu \mathrm{m}$.

era and IR-DIC optics mounted on the microscope. Patch pipettes were filled with a $\mathrm{KCl}$-based solution containing the following (in $\mathrm{mM}$ ): 140 $\mathrm{KCl}, 10 \mathrm{NaCl}, 2 \mathrm{MgCl}_{2}, 5 \mathrm{HEPES}, 0.5 \mathrm{EGTA}, 3 \mathrm{Na}_{2} \mathrm{ATP}$, and 5 glucose, $\mathrm{pH}$ adjusted to 7.3 with $\mathrm{KOH}$. This solution was supplemented with $0.2 \%$ neurobiotin [molecular weight (MW) 287, charge +1; Vector Labs] and $0.2 \%$ Lucifer yellow (di-lithium salt; MW 443 , charge -2 ) or $0.2 \%$ fluorescein dextran (MW 10 000, anionic; Invitrogen). These dyes are widely used in studies of gap junction permeability; some gap junctions in mammalian cochlear supporting cells display selectivity between these molecules of similar size but contrasting charge (Jagger and Forge, 2006; Taylor et al., 2012). Pipette solutions were filtered at $0.2 \mu \mathrm{m}$ and centrifuged to remove small, insoluble particles. Pipettes had an access resistance of 2-3M $\Omega$, as measured in artificial perilymph. Dyes were injected via the patch electrode during 5 min whole-cell recordings. Lucifer yellow or fluorescein dextran fluorescence was imaged immediately after the experiment via the video camera. For confocal analysis, within 5 min of the termination of the recording, cells or slices were fixed in 4\% PFA for $30 \mathrm{~min}$ at room temperature. To detect neurobiotin, slices were permeabilized ( $0.1 \%$ Triton X-100 for $40 \mathrm{~min})$, blocked ( $0.1 \mathrm{M} \mathrm{L}$-lysine, at $35^{\circ} \mathrm{C}$ for $40 \mathrm{~min}$ ), and incubated for $2 \mathrm{~h}$ in Alexa Fluor 555-conjugated streptavidin (1:1000; Invitrogen). Measurements of supporting cell widths were performed using Zeiss LSM software and were taken at a depth of $10 \mu \mathrm{m}$ from the luminal surface, a position that was approximately coincident with the position of hair cell nuclei in control slices.

\section{Results}

Whole-mount preparations of the BP were viable for several days in culture and retained the key cell types of the auditory epithelium, namely the hair cells and supporting cells (Fig. 1A). As shown previously for posthatch organotypic cultures (Oesterle et al., 1993; Frenz et al., 1998; Shang et al., 2010), this in vitro model could recapitulate processes of epithelial repair and regeneration that follow aminoglycoside ototoxicity in vivo. As observed in the adult chicken after chronic injections of aminoglycosides in vivo (Hirose et al., 2004; Mangiardi et al., 2004), incubation of BP cultures in $1 \mathrm{~mm}$ gentamicin activated hair cell death (apparent within $6 \mathrm{~h}$; data not shown) and the subsequent ejection of their corpses from the sensory epithelium within $24 \mathrm{~h}$ (Fig. 1B). Subsequent incubation of the whole mounts in gentamicin-free medium led to the disappearance of the corpses from the epithelium's luminal surface (Fig. 1C) concomitant with an expansion of the supporting cells and, within 3-5 d, there was the appearance of de novo hair cells identified by their characteristic immature hair bundles (Fig. 1D).

\section{Connexin expression and dye coupling during ototoxic damage and repair}

Having confirmed that the organotypic explant model provided a homeostatic environment compatible with normal epithelial repair and recovery, we next examined connexin expression during the period of gentamicin-induced damage and repair using qualitative immunofluorescence (Fig. 2). Similar to our previous observations (Nickel et al., 2006), there was a differential localization of chicken connexin43 (cCx43) and cCx30 immunofluorescence within the undamaged BP sensory epithelium imaged in transverse cryosections prepared from cultures incubated for $24 \mathrm{~h}$ in gentamicin-free medium (Fig. 2, control). During $24 \mathrm{~h}$ of gentamicin incubation, there was a progressive decrease of cCx43 immunofluorescence within the sensory epithelium, whereas cCx30 expression appeared unchanged. The level of cCx43 expression recovered gradually during $2 \mathrm{~d}$ of incubation in gentamicin-free medium such that distinct labeling could again be seen in the region just beneath the luminal surface of the epithelium. In agreement with previous work (Nickel et al., 2006), in the sensory epithelium of control utricular macula cultures, there was little detectable $\mathrm{cCx} 43$ immunofluorescence, whereas cCx30-labeled puncta were observed throughout (data not shown). Neither cCx43 nor cCx30 immunofluorescence changed noticeably after gentamicin-induced hair cell loss from the utricle.

In our previous study using RT-PCR analysis and in situ hybridization, we identified a novel third connexin isoform expressed within the BP, namely cCx26 (Nickel et al., 2006). This was suggested as the avian ortholog of mammalian $\mathrm{Cx} 26$ based on their sequence homology of $\sim 75 \%$. In new experiments, however, antibodies raised to detect mammalian Cx26 did not label sections of control BP (data not shown). This lack of reactivity may be explained by nonhomology between the avian and mam- 
A
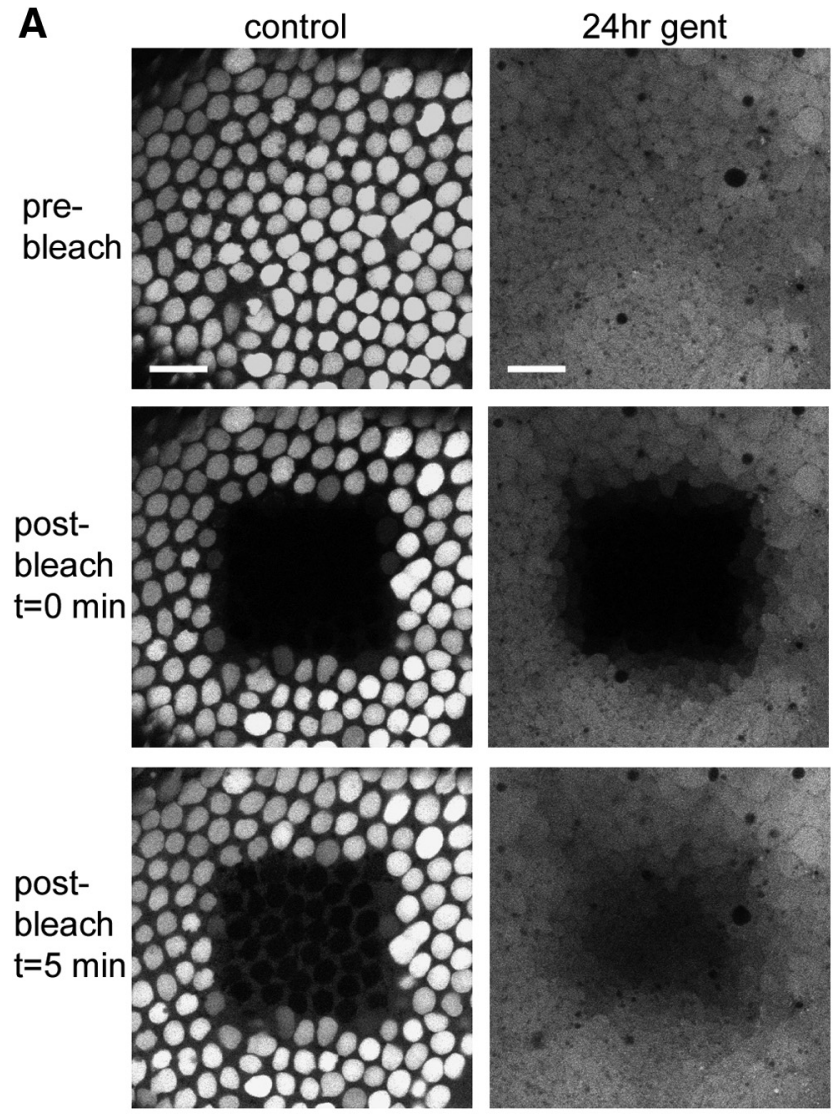

B

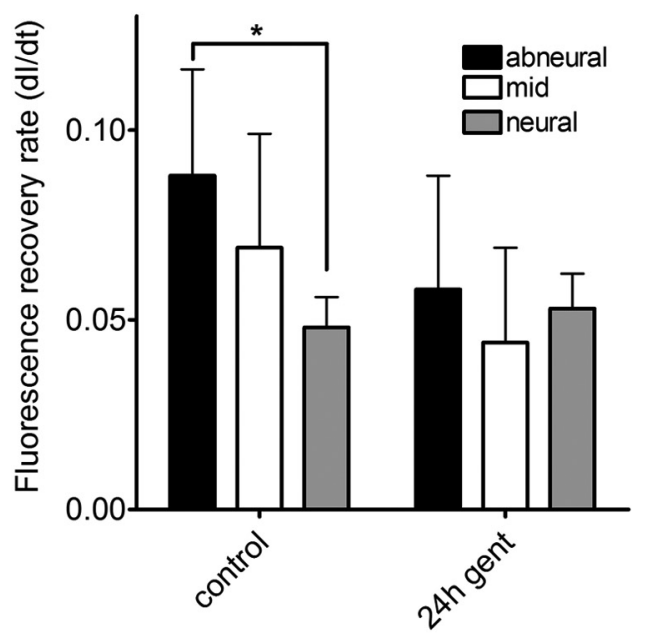

Figure 3. FRAP experiments in calcein-loaded BP explant cultures. $A$, Single optical sections of calcein fluorescence in control explants (cultured $2 \mathrm{~d}$ ) and explants cultured $24 \mathrm{~h}$ in $1 \mathrm{~mm}$ gentamicin, immediately before bleaching (top), immediately after bleaching ( $t=0 \mathrm{~min}$, middle), and 5 min after bleaching (when the diffusion equilibrium of calcein is approached, bottom). Gentamicin causes complete loss of hair cells, with supporting cells expanding to fill the resulting spaces. In the control explant, fluorescence recovers within supporting cells, but there is no recovery in hair cells. In the gentamicin-treated explant, there is comparable fluorescence recovery within supporting cells after bleaching. Scale bars, $20 \mu \mathrm{m}$. $\boldsymbol{B}$, Comparison of instantaneous fluorescence recovery rates (measured at $t=0$ ) along the abneural-neural axis between control explants $(n=4)$ and explants cultured for $24 \mathrm{~h}$ in gentamicin $(n=3)$. The mean recovery rates of fluorescence intensity $( \pm S D)$ are calculated for different regions of interest within the bleached area. In control cultures, there is significantly faster recovery in the abneural side of the explant compared with the neural side $\left({ }^{*} p<0.05\right.$, unpaired $t$ test). In gentamicin-treated explants, the recovery rate is even across the bleached area; there is no regional asymmetry in fluorescence recovery. malian orthologs in the specific regions these antibodies target. Attempts were made to generate a cCx26-specific antiserum, but these were without success.

To determine whether the decrease of $\mathrm{cCx} 43$-labeled gap junctions affected the kinetic properties of intercellular coupling between supporting cells, FRAP experiments were performed on $\mathrm{BP}$ explants after the $24 \mathrm{~h}$ exposure to gentamicin (Fig. $3 A$ ). As we described previously (Nickel et al., 2006), after calcein-AM loading of control cultures, there was a distinct pattern of brightly fluorescent hair cells surrounded by weakly fluorescent supporting cells. In gentamicin-treated cultures, there was a homogeneous weak fluorescence from supporting cells. After laser bleaching, there was a loss of fluorescence from hair cells and/or supporting cells within the exposed square. In control cultures, the calcein fluorescence intensity within supporting cells recovered to equilibrium within $\sim 5 \mathrm{~min}$, but not within hair cells. In gentamicin-treated cultures, fluorescence within supporting cells recovered to comparable levels, suggesting that gap junctional coupling was still operative after the ototoxic insult. We have previously reported regionally asymmetric dye transfer in calcein-loaded BP explants under normal conditions (Nickel et al., 2006). In those experiments, there was a faster fluorescence recovery rate measured in ROIs at the abneural edge of the $\mathrm{BP}$ compared with ROIs in the neural region. Here, asymmetric calcein transfer was again observed in control explants, but the abneural/neural asymmetry was absent after hair cell loss (Fig. 3B).

\section{cCx26 and $\mathrm{cCx} 30$ subunits assemble to form functional} homomeric or heteromeric gap junction channels in vitro Previous in situ hybridization experiments demonstrated coexpression of $\mathrm{cCx} 26$ and $\mathrm{cCx} 30$ within supporting cells of the BP sensory epithelium (Nickel et al., 2006), but we have been unable to confirm colocalization of protein expression for these subunits. As an alternative approach, we have used a heterologous expression system in which we could study cCx26 and/or cCX30 subunits in vitro to determine whether they are likely to oligomerize to form gap junctions in vivo. HeLa cells, which are naturally deficient in known connexins, can be transfected with the connexin cDNA of interest to examine them specifically (Marziano et al., 2003; Matos et al., 2007). Using this system, we tested the hypothesis that $\mathrm{cCx} 26$ and $\mathrm{cC} \times 30$ can colocalize to single gap junction plaques, so they have the opportunity to form heteromeric channels as observed in the mammalian cochlea (Forge et al., 2003; Jagger and Forge, 2006). In HeLa cells transfected transiently with cDNA for cCx26-AcGFP, fluorescently tagged cCx 26 was localized by confocal microscopy to large intercellular plaques and to smaller intracellular puncta (Fig. 4A). Comparable results were found for DsRed-tagged c $\mathrm{Cx} 30$ (Fig. 4B). In cells coexpressing cCx26-AcGFP and cCx30-DsRed, gap junctional plaques labeled with either or both of the fluorescent tags were evident between some cells (Fig. 4C). In separate experiments, the intercellular plaques could be identified in live cells under epifluorescence illumination, thus allowing candidate cells to be selected for dye injection (Fig. $4 D-F$ ). In $3 / 4$ recordings from cells expressing cCx26-AcGFP only, there was a large whole-cell membrane capacitance $(30-48 \mathrm{pF})$ and subsequent intercellular transfer of Lucifer yellow (Fig. $4 D$ ), findings consistent with functional gap junctional coupling. Comparable observations were seen in $6 / 6$ cells expressing cCx30-DsRed alone (Fig. 4E, 28-60 pF) and in 5/7 cells coexpressing cCx26-AcGFP and cCx30-DsRed (Fig. 4F, 25-88 pF). In recordings from cells without connexin-labeled plaques, the capacitance measurements were smaller $(10-17 \mathrm{pF})$ and there was no Lucifer yellow transfer (4/4 recordings; data not shown). These experiments suggested that $\mathrm{c} C \mathrm{C} 26$ and $\mathrm{cCx} 30$ can colocalize to single 
cC×26-AcGFP
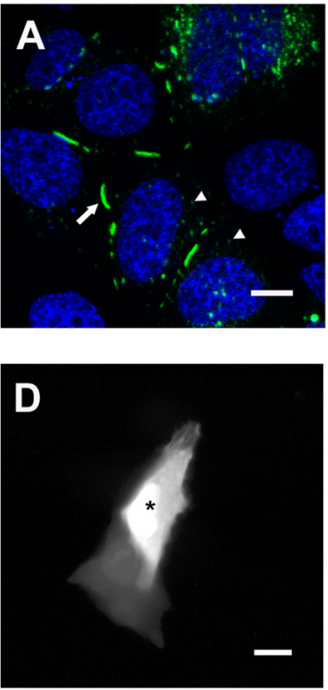

cCx30-DsRed
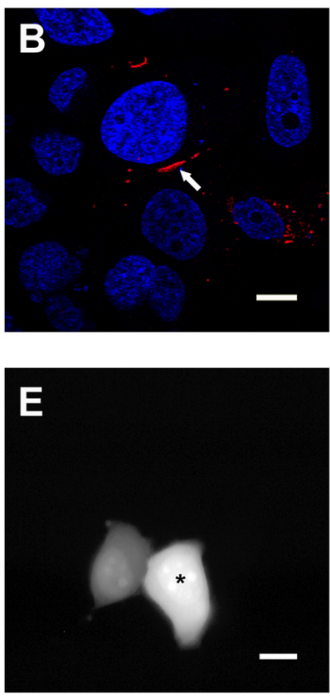

cC×26-AcGFP cCx30-DsRed
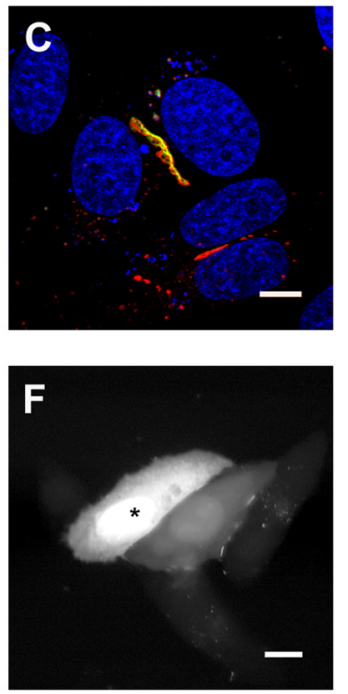

Figure 4. $\quad c(x 26$ and $c(x 30$ may assemble to form functional gap junctions. A, Postfixation confocal localization of AcGFPtagged cCx26 expressed in HeLa cells. c $\mathrm{C} \times 26$ is detected in intercellular plaques between adjacent cells (arrow) and within small intracellular puncta (arrowheads). Nuclei are stained using DAPI (blue). $\boldsymbol{B}$, DsRed-tagged c $C \times 30$ also localizes to gap junctional plaques. $\boldsymbol{C}$, In cells coexpressing $\mathrm{c}(\mathrm{X} 26$ and $\mathrm{c}(\mathrm{X} 30$, there are plaques double labeled with AcGFP and DsRed and also some singly labeled plaques. $\boldsymbol{D}-\boldsymbol{F}$, Epifluorescence videomicrographs tracking the transfer of Lucifer yellow between connexin-expressing HeLa cells after whole-cell recordings. In cells expressing $C(x 26$ alone $(\boldsymbol{D}), \mathrm{C} \times 330$ alone $(\boldsymbol{E})$, or in cells coexpressing $\mathrm{Cx} 26$ and $\mathrm{Cx} 30$ $(\boldsymbol{F})$, Lucifer yellow fluorescence is detected in the injected cell $\left(^{*}\right)$ and at least one adjacent cell. Scale bars, $10 \mu \mathrm{m}$.
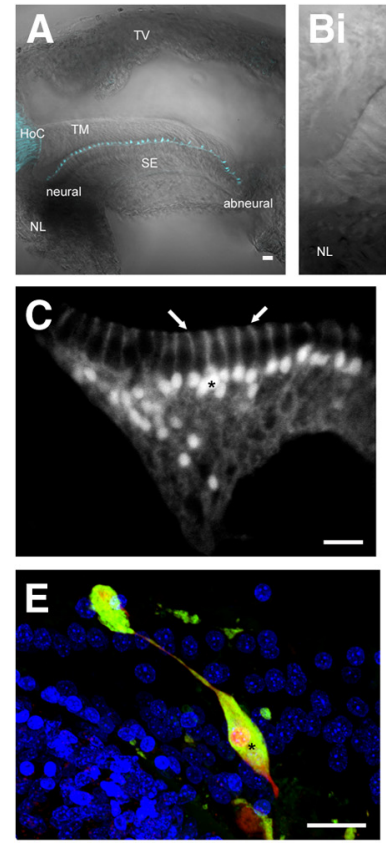
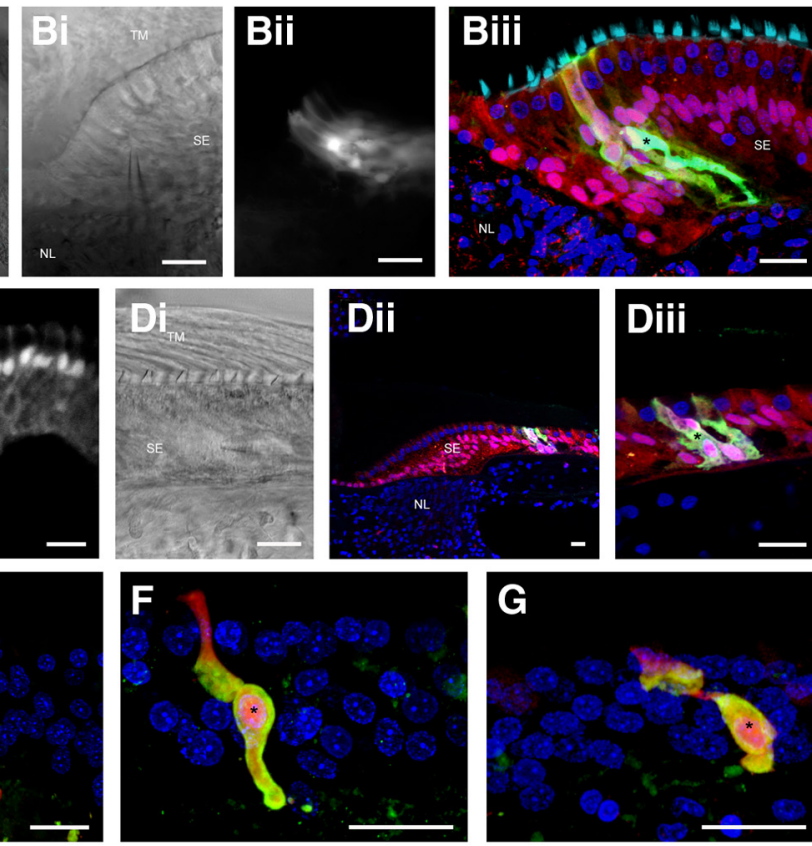

Figure 5. Dye transfer in slice preparations of cultured BP explants. $A$, Photomicrograph of a BP slice preparation used in the experiment shown in $\boldsymbol{B}$ and $\boldsymbol{C}$ counterstained with fluorescent phalloidin to label F-actin (cyan). HoC, Homogene cells; NL, neural limbus; TM, tectorial membrane; TV, tegmentum vasculosum; SE, sensory epithelium. Bi, IR-DIC videomicrograph taken during a whole-cell patch recording from a supporting cell at the neural edge of the sensory epithelium. Bii, Epifluorescence videomicrograph showing resulting Lucifer yellow transfer between supporting cells. Biii, Confocal projection showing neurobiotin (red) and Lucifer yellow (green) distribution in the same slice after PFA fixation. The injected cell is denoted by an asterisk. Nuclei are stained using DAPI (blue). Cells containing neurobiotin have $\mathrm{red} / \mathrm{blue} \mathrm{double-labeled} \mathrm{nuclei.} \mathrm{C,} \mathrm{Single} \mathrm{confocal} \mathrm{image} \mathrm{after} \mathrm{a} \mathrm{separate} \mathrm{recording} \mathrm{showing} \mathrm{the} \mathrm{distribution} \mathrm{of} \mathrm{neurobiotin} \mathrm{in} \mathrm{neural} \mathrm{region}$ supporting cells. Phalangeal processes extend from the cell body toward the luminal surface (arrows). Neurobiotin is not detected in hair cells. Di, IR-DIC videomicrograph taken during a whole-cell patch recording from a supporting cell toward the abneural edge of the sensory epithelium. Dii, Diii, Confocal projections showing the resulting distributions of neurobiotin (red) and Lucifer yellow (green). E-G, Examples of dye injections into supporting cells during transient bath application of gap junction blocker MFA $(200 \mu \mathrm{M})$. Distinct delicate $(\boldsymbol{E})$ and thick $(\boldsymbol{F})$ supporting cell types are found toward the neural edge and thick cells are found toward the abneural edge $(\boldsymbol{G})$ of the sensory epithelium. The phalangeal process of the thick cell in the neural region $(\boldsymbol{F})$ measured $1.8 \mu \mathrm{m}$ across. Scale bars, $20 \mu \mathrm{m}$. gap junction plaques, but the resulting (homomeric or heteromeric) channels share similar functional properties, such as their permeability to charged dye molecules. This is in contrast to observations for mammalian Cx26-containing and Cx30-containing channels, which demonstrate a differential permeability to anionic tracer molecules (Marziano et al., 2003). Indeed, the functional properties of $\mathrm{cCx} 30$ may be quite distinct from those of mammalian Cx30, which restricts the passage of large anionic dyes.

Gap junctional coupling in slice preparations of the cultured basilar papilla

The preservation of intercellular connectivity within slice preparations of the mammalian cochlea has enabled investigation of GJIC in sensory and nonsensory tissues (Jagger and Forge, 2006; Jagger et al., 2010; Kelly et al., 2011; Taylor et al., 2012; Forge et al., 2013). To investigate the properties of GJIC between avian supporting cells in situ, we have developed a novel slice preparation of the cultured BP, which presents the sensory and nonsensory tissues in a transverse orientation (Fig. 5A). After similar dye injection procedures to our previous studies of the mammalian cochlea, whole-cell patch-clamp recordings could be readily performed from supporting cells observed under infrared videomicroscopy (Fig. 5Bi). Whole-cell recordings were performed over a timescale compatible with observations within our previous FRAP study in which recovery was complete with $5 \mathrm{~min}$ (Nickel et al., 2006). After the termination of the recording, careful retraction of the patch pipette enabled formation of an electrically tight membrane patch (resistance $\sim 1 \mathrm{G} \Omega$ ) and injected fluorescent dyes could be observed immediately via epifluorescence videomicroscopy (Fig. 5Bii). After brief formaldehyde fixation of the slices, confocal projections enabled tracing of both neurobiotin and Lucifer yellow within the supporting cell syncytium (Fig. 5Biii). The majority of supporting cells at the neural edge of the dye-filled syncytium appeared to span the baso-apical extent of the epithelium, each with a phalangeal process extending to the luminal surface and forming a calyceal structure around the hair cells. These cells likely correlate with the "thick" type of supporting cells identified in E19 chicks using clonal analysis techniques (Fekete et al., 1998). Importantly, fluorescence within single confocal images was restricted to the supporting cells only, with no signal emitting from adjoining hair cells (Fig. 5C). In the neural region of one slice, 
the thickness of the phalangeal processes at a depth corresponding to the hair cell nuclei (measured in single confocal images at 10 $\mu \mathrm{m}$ from the luminal surface) was $1.74 \pm$ $0.22 \mu \mathrm{m}(n=23)$ thick type supporting cells were also evident in the abneural region (Fig. 5D).

Consistent with the observations of intercellular calcein transfer, the gap junctions between supporting cells close to the neural edge (Fig. 5B, typical of 8 injections) and abneural edge (Fig. 5D, typical of 6 injections) of the epithelium were permeable to both neurobiotin tracer and Lucifer yellow. This is in contrast to observations in mammalian cochlea, in which gap junctions between Deiters' cells allow passage of neurobiotin, but not of Lucifer yellow (Jagger and Forge, 2006; Taylor et al., 2012). There was, however, no transfer of the high-MW fluorescein dextran (MW 10 000; data not shown). Additional evidence that the observed intercellular transfer of neurobiotin and Lucifer was mediated via gap junctions was obtained from experiments using pharmacological blockers. Calcein transfer via BP gap junctions is blocked by carbenoxolone (Nickel et al., 2006). In preliminary patch-clamp experiments in the present study, we found that, although bath applied $100 \mu \mathrm{M}$ carbenoxolone did block GJIC evident as decreases of intercellular conductance and membrane capacitance, its effects were irreversible on washout. Comparable inhibition of junctional conductance and capacitance could also be achieved by meclofenamic acid (MFA), another recognized gap junction blocker (Pan et al., 2007; Kelly et al., 2012; Toychiev et al., 2013), but this block was reversible on washout and subsequently repeatable. When recordings were performed in the presence of $200 \mu \mathrm{M}$ MFA, there was no intercellular spread of either neurobiotin or Lucifer yellow (Fig. 5E-G), confirming the effects of MFA on GJIC. The restriction of dyes to the injected cell enabled closer inspection of the morphology of individual supporting cells. Some cells at the neural edge often spanned the whole baso-apical extent of the epithelium in a manner similar to thick supporting cells, but these cells had a cell body region close to the basilar membrane and a distinctive fine cytoplasmic process extending apically to a head structure within the hair cell region (Fig. 5E). These cells likely correlate with the "delicate" supporting cells described previously and proposed as putative precursor cells (Fekete et al., 1998). The characteristic morphology of thick supporting cells could also be delineated clearly when gap junctions were blocked (Fig. $5 F, G$ ).

\section{Functional and morphological changes in supporting cells} during ototoxic damage and repair

Dye injections in supporting cells from gentamicin-damaged BP explants yielded similar results to those from control cultures, with comparable intercellular transfer of neurobiotin and Lucifer yellow (Fig. 6A). The dye filling revealed that supporting cells had expanded after the loss of hair cells, particularly in the apical region. This was a

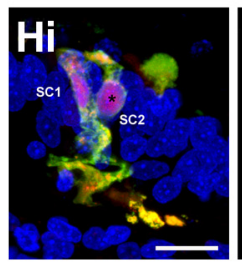

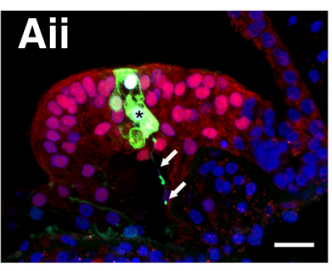
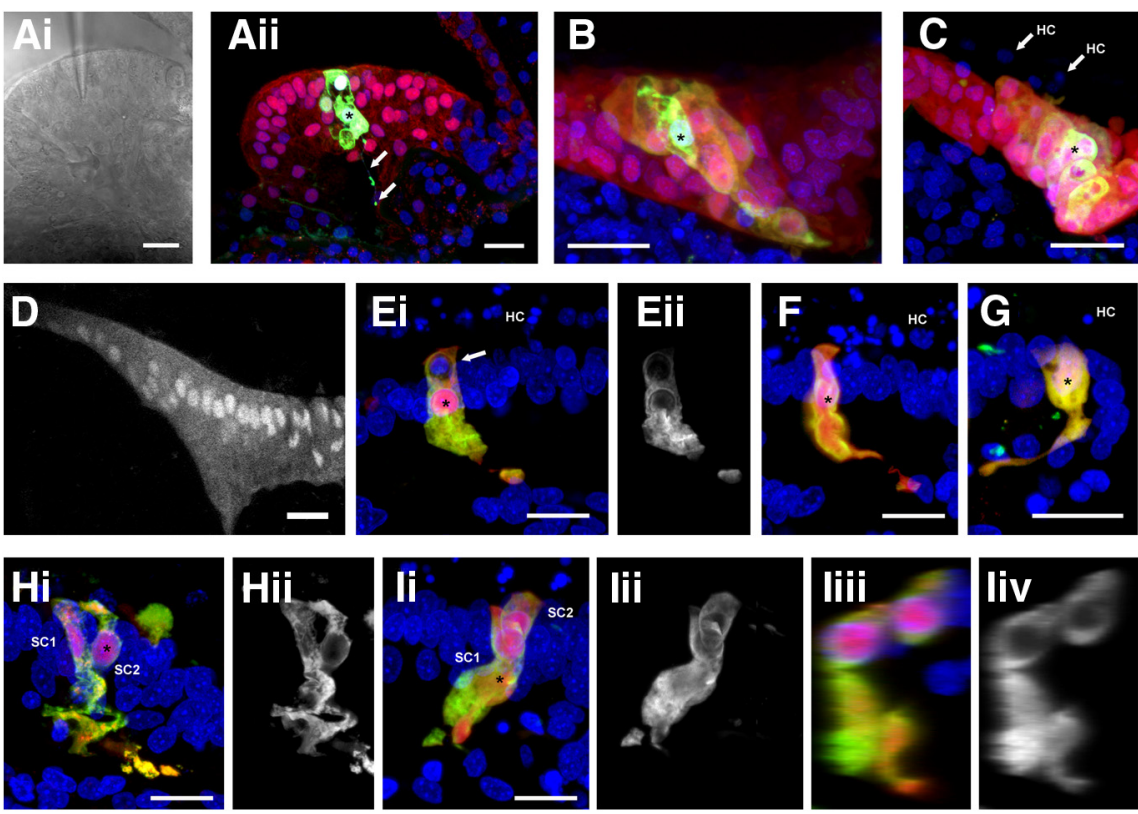

Figure 6. Supporting cell expansion in gentamicin-damaged BP. A-C, Examples of recordings in slice preparations of BP explants cultured for $24 \mathrm{~h}$ in the presence of $1 \mathrm{~mm}$ gentamicin under $\mathrm{GJIC}$-permissive conditions. Ai, IR-DIC videomicrograph taken , Neurobiotin and Lucifer yellow transfer in supporting cells at the abneural edge of the distal region. Pyknotic nuclei of ejected . Lucifer yellow fluorescence alone is shown in Hii. Ii, Both dyes are detected in an overlying supporting cell pair after an injection in the midregion (Iii shows Lucifer yellow alone). liii, The spatial relationship between the two cells is demonstrated by an orthogonal projection of neurobiotin and Lucifer yellow fluorescence (Lucifer yellow alone is shown in liv). Scale bars, $20 \mu \mathrm{m}$.

consistent observation in various locations within the BP (Fig. $6 B-$ $D)$. Whereas the supporting cells in an untreated slice had thin phalangeal processes (Fig. 5C), in a corresponding region of a slice from a gentamicin-treated $\mathrm{BP}$, the supporting cells were significantly wider $(4.63 \pm 0.84 \mu \mathrm{m}, n=16, p<0.0001$, unpaired $t$ test). This apical expansion was demonstrated in individual cells when gap junctions were blocked transiently using $200 \mu \mathrm{M}$ MFA (Fig. 6E-G). The restricted dye spread in the presence of MFA also delineated subcellular features such as a "foot" structure, connecting the cell body to the basilar membrane (Fig. $6 E-G$ ). After some experiments, despite the presence of MFA, the dyes were apparent in cell pairs, clearly revealed by the neurobiotin-staining of two near-adjacent nuclei (Fig. $6 H, I$ ). In these injections, there was usually one supporting cell that spanned the distance between the basilar membrane and the luminal surface of the epithelium and a second, smaller cell located at the luminal border. In the example shown in Figure 6I, the smaller cell was directly overlying the larger cell within the slice and confocal projection could not easily distinguish the pair (Fig. 6Ii,Iii). However, orthogonal projections more clearly defined the cells' morphology and the spatial relationship between them (Fig. 6Iiii,Iiv). 


\section{A low conductance SC}

\section{high conductance SC}
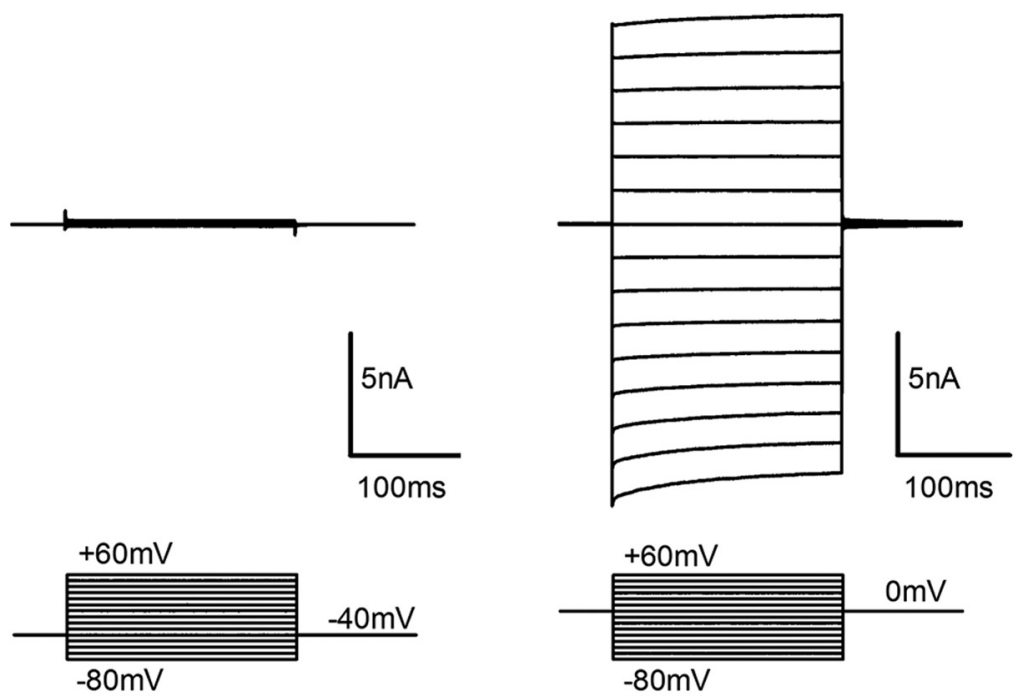

B

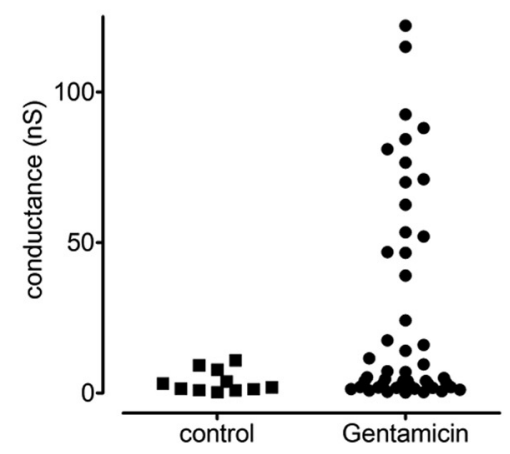

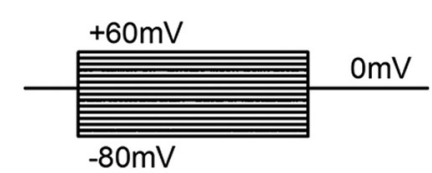

C

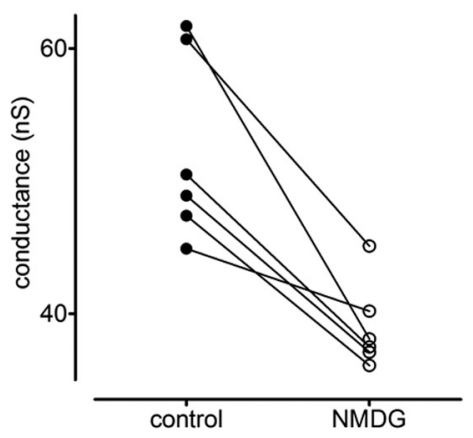

Figure 7. Divergent electrophysiological phenotypes of supporting cells in gentamicin-damaged BP. A, Whole-cell patch recordings during transient application of $200 \mu \mathrm{M}$ MFA from individual supporting cells in a slice preparations from gentamicindamaged BP explants. One neural edge supporting cell (dye injection is shown in Fig. $6 \mathbf{D}$ ) had a membrane conductance $<2 \mathrm{nS}$ (left, slope conductance measured between $-20 \mathrm{mV}$ and $+20 \mathrm{mV}$ ). Under the same conditions, another neural edge supporting cell (shown in Fig. $6 \boldsymbol{E}$ ) had a membrane conductance $>100 \mathrm{nS}$ (right). In both recordings, Lucifer yellow fluorescence was restricted to a single cell, confirming a lack of intercellular coupling. $\boldsymbol{B}$, Slope conductance measurements from supporting cells in control and gentamicin-treated BPs. There was a larger spread of conductance measurements from the gentamicin-treated cells, with high conductance values in cells from all locations along the neural-abneural axis. C, Whole-bath replacement of $\mathrm{Na}^{+}$ions with N-methyl-D-glutamine (NMDG) partially reduced the conductance of gentamicin-treated cells.

During the bath application of MFA, whole-cell recordings from supporting cells allowed isolation of voltage-gated currents normally masked by the gap junctional conductance (Fig. 7). Supporting cells from gentamicin-damaged BP could be described broadly as having a low membrane conductance (typically $1-5 \mathrm{nS}$ measured between $-20 \mathrm{mV}$ and $+20 \mathrm{mV}$; Fig. $7 A$, left) or high conductance (typically $>20 \mathrm{nS}$; Fig. 7A, right). Supporting cells from undamaged BP displayed the low conductance phenotype only (Fig. $7 B$ ) regardless of their thick or delicate morphological classification. Low conductance cells from both conditions had membrane currents that activated and deactivated quickly and showed little voltage dependence. These properties were reminiscent of currents in supporting cells of the pigeon semicircular canal (Masetto and Correia, 1997), but gap junctional conductances were not reported in those cells. In the higher conductance cells, the voltage-activated currents displayed a slow inactivation and activation during hyperpolarizing and depolarizing steps, respectively. Attempts to identity the membrane channels mediating the large currents were unsuccessful. Blockers of weakly rectifying $\mathrm{K}^{+}$currents $\left(1 \mathrm{~mm} \mathrm{Ba}^{2+}\right.$, $n=2$ ), chloride channels (100 $\mu \mathrm{M}$ DIDS, $n=2 ; 100 \mu \mathrm{M} 9-\mathrm{AC}, n=2)$, and TRP channels (100 $\mu$ M 2-APB, $n=2)$ were all without effect. However, in $6 / 6$ cells, the conductance decreased during whole bath replacement of $\mathrm{Na}^{+}$ions with $\mathrm{N}$-methylD-glucamine (Fig. $7 C$ ), suggesting that the large currents may be mediated, at least in part, by nonselective cation channels.

\section{GJIC is essential for normal epithelial repair}

Because functional GJIC appears to be essential for normal repair in the mammalian cochlea (Forge et al., 2013), we investigated whether gap junctions contribute to epithelial repair in the avian cochlea (Fig. 8). In transverse cryosections prepared from undamaged BP cultured with $200 \mu \mathrm{M}$ MFA added to the medium for $24 \mathrm{~h}$ before fixation (control), HCS- 1 antiserum identified hair cells within a single layer at the luminal border of the sensory epithelium (Fig. 8A). In surface preparations of control explants, phalloidin labeled F-actin within the hair cell stereociliary bundles, but also at the intercellular borders, where supporting cells contact hair cells (Fig. 8B). These results suggest that chronic block of GJIC in itself does not influence hair cell survival in vitro. In gentamicin-damaged explants, HCS-1labeled hair cell corpses aggregated within a mass outside the sensory epithelium between the luminal surface (delineated by actin labeling) and the tectorial membrane (Fig. 8C) and the apical region of supporting cells had expanded to fill the space left by dying hair cells (Fig. 8D). However, in explants cultured for $24 \mathrm{~h}$ in both $1 \mathrm{~mm}$ gentamicin and $200 \mu \mathrm{M}$ MFA, the hair cells were not ejected from the epithelium (Fig. $8 E, F$ ) even though their nuclei appeared condensed (Fig. $8 E$, inset), consistent with the hair cells having begun the process of apoptosis. Separate dye injection experiments were performed in slice preparations from explants incubated in the presence of both gentamicin and MFA for $24 \mathrm{~h}$ (Fig. 9). Supporting cells in these explants did not have the expanded phenotype observed previously in explants treated with gentamicin only (Fig. 6). Instead, they more closely resembled the thick and delicate morphologies described in undamaged BP. The phalangeal processes of seven thick cells measured 1.5-2.3 $\mu \mathrm{m}$ across, a similar range to measurements in undamaged BP. The nuclei were not located luminally. At the same level of the unexpanded phalangeal processes, pyknotic hair cell nuclei were evident, confirming that dying hair cells were not fully ejected from the epithelium. Nonsteroidal anti-inflammatory drugs such as MFA are known to also inhibit cyclooxygenase (COX) isozymes, accounting for some of their therapeutic actions (Kalgutkar et al., 2000). To discount the likelihood that MFA was exerting its effects via this mechanism in our experiments, we coincubated explants with $1 \mathrm{~mm}$ gentamicin and the alternative COX inhibitor diclofenac $(100 \mu \mathrm{M})$. In these control experiments, hair cells were 
ejected as normal ( $n=2$, data not shown). This suggests that decreased prostaglandin synthesis was unlikely to be the cause of the observed MFA-associated effects on epithelial repair. Cultures coincubated with $1 \mathrm{~mm}$ gentamicin and $200 \mu \mathrm{M} 18-\beta$ glycyrrhetinic acid, another recognized gap junction blocker (Pan et al., 2007), did not undergo hair cell ejection (data not shown), further implicating GJIC with normal repair of the BP.

\section{Discussion}

Ototoxicity-associated regulation of epithelial connexins and gap

junctional coupling

Previously, our studies have resolved properties of supporting cell gap junctions in preparations of mammalian organ of Corti (Jagger and Forge, 2006) and chicken BP (Nickel et al., 2006) and identified connexin-dependent processes during epithelial repair after the loss of hair cells from the mouse cochlea (Taylor et al., 2012; Forge et al., 2013). We have now observed changes of connexin expression during ototoxic insult to the chick BP, measured concomitant alterations to the properties of intercellular dye coupling, and confirmed a role for GJIC in processes mediating the ejection of dying hair cells from the damaged epithelium. These observations expand our understanding of how gap-junction-dependent signaling contributes to normal tissue homeostasis and confirms its importance in the coordination of sensory tissue repair across different species.

By screening inner ear tissues, we previously identified chicken orthologs to the mammalian $\mathrm{Cx} 30, \mathrm{Cx} 26$ and $\mathrm{Cx} 43$, as major connexin isoforms in the avian inner ear (Nickel et al., 2006). In situ hybridization suggested that, analogous to the mammalian inner ear, cCx26 and cCx30 transcripts were expressed in sensory and ion-transporting epithelia of the cochlear duct and utricle. Furthermore, their overlapping mRNA expression pattern suggested possible colocalization within individual inner ear gap junctions similar to that found in the mammalian inner ear. Our attempts at producing an antibody targeted specifically toward chicken cCx26 have been fruitless thus far, so we have not been able to demonstrate colabeling of single gap junction plaques by cCx26 and cCx30 definitively in vivo. Heterologous expression suggested that $\mathrm{cCx} 26$ and $\mathrm{cCx} 30$ are able to colocalize within single gap junction plaques, but any resulting heteromeric cCx $26 / \mathrm{cCx} 30$ gap junction channels are unlikely to share the properties of equivalent mammalian channels, particularly because cCx30 appears to be less selective than its mammalian counterpart (Marziano et al., 2003). In the BP, we demonstrated decreased expression of $\mathrm{cCx} 43$ in response to gentamicin-induced hair cell loss and concluded that the properties of $\mathrm{cCx} 30$ alone could support the observed gap junctional communication occurring during epithelial repair. The decreased expression of $\mathrm{cx} 43$ may be permissive for the increased proliferative capacity of the damaged BP (for further discussion, see Nickel et al., 2006).

Avian inner ear gap junctions are permeable to large, anionic fluorescent tracers such as calcein and Lucifer yellow. This is in con- trast to the hearing mammalian cochlea, in which the presence of heteromeric $\mathrm{Cx} 26 / \mathrm{Cx} 30$ gap junction channels impairs the transfer of large anions between the supporting cells adjacent to the sensory hair cells (Jagger and Forge, 2006; Taylor et al., 2012). In addition, in the organ of Corti, there appears to be considerable local restriction of intercellular neurobiotin spread, suggesting compartmentalization of the supporting cells adjacent to the different hair cell types. This may be the basis of proposed distinct medial and lateral $\mathrm{K}^{+}$ recirculation pathways (Spicer and Schulte, 1998; Jagger et al., 2010). In the avian cochlea, the pathways of neurobiotin transfer appeared to be less restricted or compartmentalized. We have observed comparable unrestricted neurobiotin coupling in the adult mouse utricle (R. Taylor and D. Jagger, unpublished data), where the supporting cells may also be relatively unspecialized.

The specific localization of cCx43 to abneural BP supporting cells seems linked to the asymmetric dye coupling observed normally between those cells, a specialization not seen in the chick utricle, where Cx43-labeled puncta are not observed (Nickel et al., 2006). The apical expansion of BP supporting cells in response to hair cell loss appeared to be associated with cCx30-dependent GJIC. An equivalent mechanism is interrupted in Cx30-null mice, in which the bodies of gap-junction-deficient Deiters' cells fail to fill the spaces left by dying outer hair cells and also subsequently fail to migrate during formation of the "flat" epithelium that remains after all hair cells have died (Forge et al., 2013). How connexin-mediated signaling coordinates supporting cell expansion and corpse removal remains open to speculation, but it may be important to study 


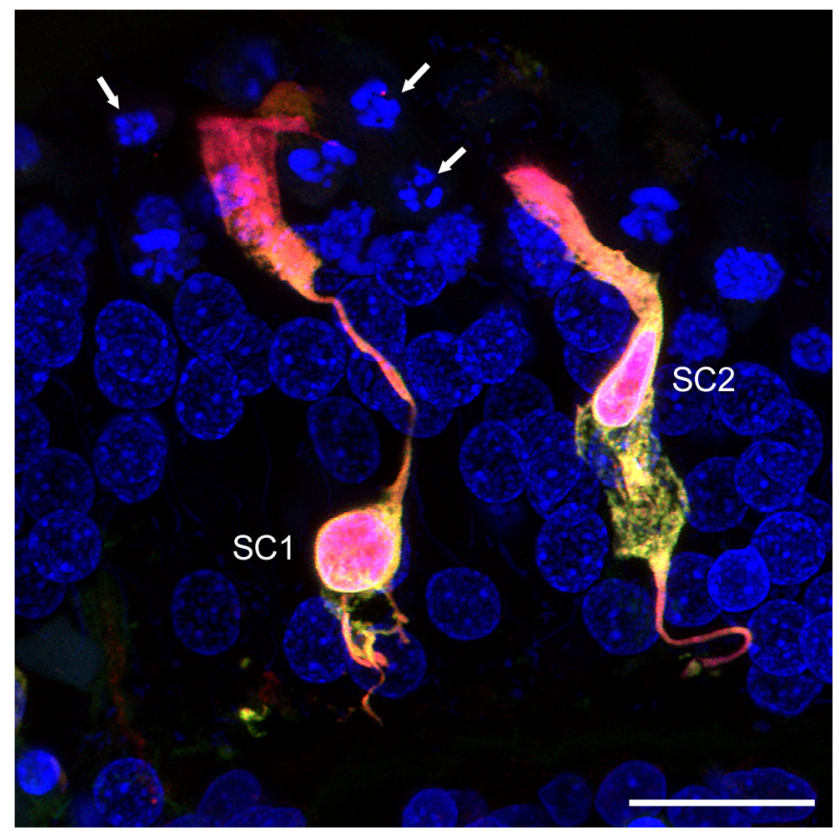

Figure 9. Gap junction inhibition during ototoxic damage prevents supporting cell expansion. Whole-cell dye injections of neurobiotin (red) and Lucifer yellow (green) into separate supporting cells close to the neural edge of a slice preparation from a BP cultured $24 \mathrm{~h}$ in $1 \mathrm{~mm}$ gentamicin and $200 \mu \mathrm{M}$ MFA revealing unexpanded cell bodies and phalangeal processes. Pyknotic nuclei of hair cell corpses are evident within the epithelium (arrows). One cell (SC1) retains a delicate phenotype, with a very thin cytoplasmic stalk rising from the nucleus (located near the basilar membrane) to an apical head structure at the luminal surface. The extracellular recording medium was supplemented with $200 \mu \mathrm{m}$ MFA. The slope conductance of this cell was $\sim 100 \mathrm{nS}$. The other supporting cell (SC2) with a thick phenotype has a phalangeal process (measuring $1.8 \mu \mathrm{m}$ across) projecting from the cell body and its nucleus is located within the midsection of the sensory epithelium. The whole-cell slope conductance of this cell was $\sim 1 \mathrm{nS}$. Scale bar, $20 \mu \mathrm{m}$.

mechanisms such as gap-junction-mediated $\mathrm{Ca}^{2+}$-waves and the subsequent activation of $\mathrm{Ca}^{2+}$-dependent processes that regulate cell volume and motility.

\section{Heterogeneity of supporting cells in the avian auditory sensory epithelium}

It is not clear whether spatial or temporal separation of BP regenerative responses results from heterogeneity of supporting cells or plasticity among a homogenous population. Although the majority of molecular markers for supporting cells tested so far are expressed in them all (e.g., sox2), other markers such as Fgfr3 (BerminghamMcDonogh et al., 2001), Prox1 (Stone et al., 2003), and Cx43 (Nickel et al., 2006) are differentially expressed along the neural edge, indicating that molecular characteristics of supporting cells may not be identical. Previous studies have identified stem-cell-like characteristics in $\sim 4 \%$ of supporting cells, namely the detection of proliferating cell nuclear antigen in the undamaged BP (Bhave et al., 1995) and multiple divisions after hair cell loss (Stone et al., 1999). This coincides with the appearance of the morphologically distinct delicate supporting cell type, which has a basally located nucleus with a thin cytoplasmic process to the apical lumen (Fekete et al., 1998). These cells were proposed as precursor cells that were quite morphologically distinct from the thick type that formed the majority of supporting cells in the E19 chick BP. Here, injection of dye tracers in the undamaged and damaged BP identified varying morphological supporting cell types. During transient application of MFA, all supporting cells in control slices had very low membrane conductance (typically 1-10 nS), reflecting a dearth of membrane ion channels.
Morphologically, we identified thick and delicate cells near the neural edge in undamaged BP, but these were indistinguishable electrophysiologically. In gentamicin-treated explants, we identified a subset of supporting cells that had higher membrane conductance (typically 30-100 nS) and membrane potential close to $0 \mathrm{mV}$. There was no clear correlation between the occurrence of the higher conductance and a particular morphological supporting cell type. Although this conductance was not identified, we speculate that it may indicate the activation of physiological intracellular signaling pathways involved with supporting cell expansion, so it deserves further study.

\section{Tissue homeostasis, regeneration, and cell turnover in the} damaged avian inner ear

An essential aspect of normal tissue homeostasis is the replacement of dead or damaged cells. Two distinct mechanisms maintain the cellular integrity of a tissue: cell turnover in response to a continuous loss of differentiated cells and regeneration after a pathological stimulus that causes the death or damage of a cell population. It is now well established that, after hair cell loss in the nonmammalian inner ear, supporting cells give rise to new hair cells by two distinctive mechanisms: direct trans-differentiation and cell division (Roberson et al., 2004; Taylor and Forge, 2005). In the chicken BP, the principal model for hair cell regeneration in warm-blooded vertebrates, supporting cells are quiescent in the undamaged sensory epithelium but, in response to hair cell loss, auditory supporting cells reenter the cell cycle, proliferate, and subsequently differentiate into new functional hair cells (Stone and Cotanche, 2007). After ototoxic damage, mitosis is more prevalent toward the neural edge of the $\mathrm{BP}$, whereas trans differentiation is more prevalent abneurally (Cafaro et al., 2007). In contrast to the BP, the postembryonic vestibular epithelia produce hair cells continuously, which is thought to occur as a result of spontaneous apoptosis of hair cells (Warchol et al., 2001).

BP supporting cells enter the S-phase 12-24 h after the onset of a damaging stimulus and proliferation reaches its maximum within 2-3 d before returning to predamaged levels after 5-7 d (Stone et al., 1999). Supporting cells give rise to either hair cells or supporting cells through symmetric or asymmetric cell division (Stone and Rubel, 2000; Stone and Cotanche, 2007). In our dye injection experiments on gentamicin-damaged BP in which gap junctions were blocked transiently, there were incidences of dye-filled cell pairs. These pairs had nuclei located toward the luminal surface of the epithelium and, although their apical pole extended toward the luminal surface, one cell of the pair appeared to remain in contact with the basilar membrane. We suggest that these observations reflect the late stages of asymmetric cell division activated by the ototoxic insult (Stone and Cotanche, 2007; Brignull et al., 2009; Wan et al., 2013), with the smaller of the pair possibly representing a newly regenerated hair cell precursor. An alternative possibility is that these cell pairs are exclusively coupled via MFA-resistant gap junctions. Future studies using our slice preparation approach to further characterize the mechanisms of hair cell regeneration could incorporate an analysis of markers such as Atoh1, which is expressed in dividing supporting cells or newly postmitotic cells (Cafaro et al., 2007). We also observed cells apparently mediating endocytic removal of hair cell corpses (Bird et al., 2010), suggesting that homeostatic repair mechanisms endure vibratome sectioning of explants. The slice preparation should prove to be a powerful new tool in the study of damage and repair mechanisms in the avian inner ear. 


\section{References}

Abrashkin KA, Izumikawa M, Miyazawa T, Wang CH, Crumling MA, Swiderski DL, Beyer LA, Gong TW, Raphael Y (2006) The fate of outer hair cells after acoustic or ototoxic insults. Hear Res 218:20-29. CrossRef Medline

Bermingham-McDonogh O, Stone JS, Reh TA, Rubel EW (2001) FGFR3 expression during development and regeneration of the chick inner ear sensory epithelia. Developmental biology 238:247-259. CrossRef Medline

Bhave SA, Stone JS, Rubel EW, Coltrera MD (1995) Cell cycle progression in gentamicin-damaged avian cochleas. J Neurosci 15:4618-4628. Medline

Bird JE, Daudet N, Warchol ME, Gale JE (2010) Supporting cells eliminate dying sensory hair cells to maintain epithelial integrity in the avian inner ear. J Neurosci 30:12545-12556. CrossRef Medline

Brignull HR, Raible DW, Stone JS (2009) Feathers and fins: nonmammalian models for hair cell regeneration. Brain Res 1277:12-23. CrossRef Medline

Cafaro J, Lee GS, Stone JS (2007) Atoh1 expression defines activated progenitors and differentiating hair cells during avian hair cell regeneration. Dev Dyn 236:156-170. CrossRef Medline

Davies S, Forge A (1987) Preparation of the mammalian organ of Corti for scanning electron microscopy. J Microsc 147:89-101. CrossRef Medline

Fekete DM, Muthukumar S, Karagogeos D (1998) Hair cells and supporting cells share a common progenitor in the avian inner ear. J Neurosci 18: 7811-7821. Medline

Forge A (1985) Outer hair cell loss and supporting cell expansion following chronic gentamicin treatment. Hear Res 19:171-182. CrossRef Medline

Forge A, Li L, Corwin JT, Nevill G (1993) Ultrastructural evidence for hair cell regeneration in the mammalian inner ear. Science 259:1616-1619. CrossRef Medline

Forge A, Li L, Nevill G (1998) Hair cell recovery in the vestibular sensory epithelia of mature guinea pigs. J Comp Neurol 397:69-88. CrossRef Medline

Forge A, Becker D, Casalotti S, Edwards J, Marziano N, Nevill G (2003) Gap junctions in the inner ear: comparison of distribution patterns in different vertebrates and assessement of connexin composition in mammals. J Comp Neurol 467:207-231. CrossRef Medline

Forge A, Jagger DJ, Kelly JJ, Taylor RR (2013) Connexin30-mediated intercellular communication plays an essential role in epithelial repair in the cochlea. J Cell Sci 126:1703-1712. CrossRef Medline

Frenz DA, Yoo H, Liu W (1998) Basilar papilla explants: a model to study hair cell regeneration-repair and protection. Acta Otolaryngol 118:651659. CrossRef Medline

Gale JE, Jagger DJ (2010) Cochlear supporting cells. In: The oxford handbook of auditory science: the ear (Fuchs PA, ed), pp 307-327. Oxford: Oxford UP.

Gale JE, Meyers JR, Periasamy A, Corwin JT (2002) Survival of bundleless hair cells and subsequent bundle replacement in the bullfrog's saccule. J Neurobiol 50:81-92. CrossRef Medline

Hirose K, Westrum LE, Cunningham DE, Rubel EW (2004) Electron microscopy of degenerative changes in the chick basilar papilla after gentamicin exposure. J Comp Neurol 470:164-180. CrossRef Medline

Jagger DJ, Forge A (2006) Compartmentalized and signal-selective gap junctional coupling in the hearing cochlea. J Neurosci 26:1260-1268. CrossRef Medline

Jagger DJ, Nevill G, Forge A (2010) The membrane properties of cochlear root cells are consistent with roles in potassium recirculation and spatial buffering. J Assoc Res Otolaryngol. In press. CrossRef

Kalgutkar AS, Crews BC, Rowlinson SW, Marnett AB, Kozak KR, Remmel RP, Marnett LJ (2000) Biochemically based design of cyclooxygenase-2 (COX-2) inhibitors: facile conversion of nonsteroidal antiinflammatory drugs to potent and highly selective COX-2 inhibitors. Proc Natl Acad Sci U S A 97:925-930. CrossRef Medline

Kelly JJ, Forge A, Jagger DJ (2011) Development of gap junctional intercellular communication within the lateral wall of the rat cochlea. Neuroscience 180:360-369. CrossRef Medline

Kelly JJ, Forge A, Jagger DJ (2012) Contractility in type III cochlear fibrocytes is dependent on non-muscle myosin II and intercellular gap junctional coupling. J Assoc Res Otolaryngol 13:473-484. CrossRef Medline Li L, Nevill G, Forge A (1995) Two modes of hair cell loss from the vestibular sensory epithelia of the guinea pig inner ear. J Comp Neurol 355:405-417. CrossRef Medline

Mangiardi DA, McLaughlin-Williamson K, May KE, Messana EP, Mountain DC, Cotanche DA (2004) Progression of hair cell ejection and molecular markers of apoptosis in the avian cochlea following gentamicin treatment. J Comp Neurol 475:1-18. CrossRef Medline

Marziano NK, Casalotti SO, Portelli AE, Becker DL, Forge A (2003) Mutations in the gene for connexin 26 (GJB2) that cause hearing loss have a dominant negative effect on connexin 30. Hum Mol Genet 12:805-812. CrossRef Medline

Masetto S, Correia MJ (1997) Electrophysiological properties of vestibular sensory and supporting cells in the labyrinth slice before and during regeneration. J Neurophysiol 78:1913-1927. Medline

Matos TD, Caria H, Simões-Teixeira H, Aasen T, Nickel R, Jagger DJ, O'Neill A, Kelsell DP, Fialho G (2007) A novel hearing-loss-related mutation occurring in the GJB2 basal promoter. J Med Genet 44:721-725. CrossRef Medline

Monzack EL, Cunningham LL (2013) Lead roles for supporting actors: critical functions of inner ear supporting cells. Hear Res 303:20-29. CrossRef Medline

Nickel R, Becker D, Forge A (2006) Molecular and functional characterization of gap junctions in the avian inner ear. J Neurosci 26:6190-6199. CrossRef Medline

Oesterle EC, Tsue TT, Reh TA, Rubel EW (1993) Hair-cell regeneration in organ cultures of the postnatal chicken inner ear. Hear Res 70:85-108. CrossRef Medline

Pan F, Mills SL, Massey SC (2007) Screening of gap junction antagonists on dye coupling in the rabbit retina. Vis Neurosci 24:609-618. CrossRef Medline

Raphael Y, Kim YH, Osumi Y, Izumikawa M (2007) Non-sensory cells in the deafened organ of Corti: approaches for repair. Int J Dev Biol 51:649 654. CrossRef Medline

Roberson DW, Alosi JA, Cotanche DA (2004) Direct transdifferentiation gives rise to the earliest new hair cells in regenerating avian auditory epithelium. J Neurosci Res 78:461-471. CrossRef Medline

Rubel EW, Furrer SA, Stone JS (2013) A brief history of hair cell regeneration research and speculations on the future. Hear Res 297:42-51. CrossRef Medline

Shang J, Cafaro J, Nehmer R, Stone J (2010) Supporting cell division is not required for regeneration of auditory hair cells after ototoxic injury in vitro. J Assoc Res Otolaryngol 11:203-222. CrossRef Medline

Spicer SS, Schulte BA (1998) Evidence for a medial K+ recycling pathway from inner hair cells. Hear Res 118:1-12. CrossRef Medline

Stone JS, Cotanche DA (2007) Hair cell regeneration in the avian auditory epithelium. Int J Dev Biol 51:633-647. CrossRef Medline

Stone JS, Rubel EW (2000) Temporal, spatial, and morphologic features of hair cell regeneration in the avian basilar papilla. J Comp Neurol 417:1-16. CrossRef Medline

Stone JS, Choi YS, Woolley SM, Yamashita H, Rubel EW (1999) Progenitor cell cycling during hair cell regeneration in the vestibular and auditory epithelia of the chick. J Neurocytol 28:863-876. CrossRef Medline

Stone JS, Shang JL, Tomarev S (2003) Expression of Proxl defines regions of the avian otocyst that give rise to sensory or neural cells. J Comp Neurol 460:487-502. CrossRef Medline

Taylor RR, Forge A (2005) Hair cell regeneration in sensory epithelia from the inner ear of a urodele amphibian. J Comp Neurol 484:105-120. CrossRef Medline

Taylor RR, Nevill G, Forge A (2008) Rapid hair cell loss: a mouse model for cochlear lesions. J Assoc Res Otolaryngol 9:44-64. CrossRef Medline

Taylor RR, Jagger DJ, Forge A (2012) Defining the cellular environment in the organ of Corti following extensive hair cell loss: a basis for future sensory cell replacement in the Cochlea. PLoS One 7:e30577. CrossRef Medline

Toychiev AH, Ivanova E, Yee CW, Sagdullaev BT (2013) Block of gap junctions eliminates aberrant activity and restores light responses during retinal degeneration. J Neurosci 33:13972-13977. CrossRef Medline

Wan G, Corfas G, Stone JS (2013) Inner ear supporting cells: rethinking the silent majority. Semin Cell Dev Biol 24:448-459. CrossRef Medline

Warchol ME, Matsui JI, Simkus EL, Ogilive JM (2001) Ongoing cell death and immune influences on regeneration in the vestibular sensory organs. Ann N Y Acad Sci 942:34-45. CrossRef Medline 